Bu makaleye atıfta bulunmak için/To cite this article:

AKKAYA, S. GEZER SEN, B. KAPIDERE, M. (2021). A Multi-Directional Assessment Related To E-Sports As A New

Game Experience Field And Socialising Tool. Atatürk Üniversitesi Sosyal Bilimler Enstitüsü Dergisi, 25 (3), 968 -

988.

\title{
A Multi-Directional Assessment Related to E-Sports as A New Game Experience Field and Socialising Tool
}

\author{
Sümeyra AKKAYA(*) \\ Burcu GEZER ŞEN (**) \\ Metin KAPIDERE (***)
}

\begin{abstract}
The aim of the research is to examine e-sports as a new game experience and socialization tool from a multidimensional perspective. The case study model, one of the qualitative research methods, was used in the study. The working group of this research consists of 22 teacher candidates studying at İn̈̈ü University, Faculty of Education, Department of Primary Education, Primary School Teaching Program in the 2020-2021 academic year. A total of 22 students, 10 males and 12 females, participated in the study. The students were determined by sampling criteria, one of the purposeful sampling methods, among those who have experience in e-sports. Data were collected with a semi-structured interview form developed by the researchers. While creating the form, support was received from 3 field experts. The interview form consisting of 4 open-ended questions prepared by the researcher was used for data collection in this study. The data collected in this study were analyzed by content analysis. According to the findings of the research, it was determined that the teacher candidates define e-sports as online participationbased digital games that require more internet use. While some of the teacher candidates' expressed the view that e-sports socialized, others argued that digital games cause screen addiction and disconnect the individual from sociality.
\end{abstract}

Keywords: E-sports, socialization, gaming, teacher candidates, digital game.

\section{Yeni Bir Oyun Deneyim Alanı ve Sosyalleşme Aracı Olarak E-Spor'a İlişkin Çok Yönlü Bir İnceleme}

Öz: Araştırmanın amacı, yeni bir oyun deneyimi alanı ve sosyalleşme aracı olarak esporun çok boyutlu bir bakış açısıyla incelenmesidir. Araştırmada nitel araştırma yöntemlerinden durum çalışması modeli kullanılmıştır. Bu araştırmanın çalı̧̧ma grubunu 2020-2021 eğitim-ögretim yllında İn̈nü Üniversitesi Ĕ̆itim Fakültesi Temel Eğitim Bölümü Sinıf Öğretmenliği Programında öğrenim gören 22 öğretmen adayı oluşturmaktadır. Çalışmaya 10'u erkek 12'si kadın olmak üzere toplam 22 öğrenci katılmıştır. Öğrenciler e-

*) Assistant Prof. Dr, İnönü University Faculty of Education Primary Education Department (email: sumeyra.akkaya@inonu.edu.tr)(D ORCID ID. https://orcid.org/ 0000-0002-9942-9848

**) Assistant Prof. Dr, Firat University Faculty of Education Primary Education Department (email: burcugezersen@firat.edu.tr) (D) ORCID ID.https://orcid.org/0000-0003-3782-2377

***) Assistant Prof. Dr, İnönü University Faculty of Education Computer Education and Instructional Technology Department (e-mail: metin.kapidere@inonu.edu.tr) (D) ORCID ID. https://orcid.org/0000-0002-0039-0710

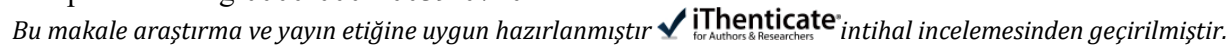


spor tecrübesine sahip olanlar arasından amaçlı örnekleme yöntemlerinden ölçüt örnekleme ile belirlenmiştir. Veriler, araştırmacılar tarafindan geliş̧tirilen yarı yapılandırılmış bir görüşme formu ile toplanmıştır. Form oluşturulurken 3 alan uzmanından destek alınmıştır. Araştırmacı tarafindan hazırlanan 4 açık uçlu sorudan oluşan görüşme formu bu çalışmada veri toplama için kullanılmıştır. Bu çalışmada toplanan veriler içerik analizi ile analiz edilmiştir. Araştırmanın bulgularına göre öğretmen adaylarının E-sporu daha çok internet kullanımı gerektiren çevrim içi katılıma dayalı dijital oyunlar olarak tanımladıkları belirlenmiştir. Öğretmen adaylarından bazıları e-sporun sosyalleştirdiği görüşünü ifade ederken bazıları ise dijital oyunların ekran bă̆ımlılı̆̆ına neden olduğunu ve bireyi sosyallikten kopardığını savunmuştur.

Anahtar Kelimeler: E-spor, sosyalleşme, ögretmen adayları, dijital oyun.

Makale Geliş Tarihi: 30.05 .2021

Makale Kabul Tarihi: 20.09.2021

DOI: $10.53487 /$ ataunisosbil.944458

\section{Introduction}

Technological developments directly or indirectly impact sports just like all other social spheres. These developments enabled electronic sports to emerge that came with video games. The electronic sports concept represents a sports field including professional and competitive video gaming (Üçüncüoğlu \& Çakır, 2017). The new information technologies and the new opportunities of contemporary media enable traditional sports to be a part of the virtual world. E-sports represents the competitive video games that gamers from all over the world find a chance to play against each other (Baltezarević \& Baltezarević, 2019).

As in media studies, the studies on sports consumption and audience often deals with motivation about what type of needs they presented media type meet and why and how individuals consume it. The sports consumption research until today mainly focused on the sports management field. Sports turned into a computer-mediated media and information technology form that includes new ways to use information technologies with the rise of e-sports. This was transformed e-sports into an interesting field of research in the information technologies field. Although e-sports are adopted in the international arena, there is still resistance regarding whether it should be adopted as a sports branch. Accordingly, the definition of the e-sports concept, drawing its borders and investigating the role of e-sports in the socialisation process of individuals play an important role (Hamari \& Sjöblom, 2017).

To understand the current status of the academic research related to e-sports and to identify the research questions, findings and tendencies in this field, studies in various research fields should be reviewed. As the studies related to e-sports are varied, the game-related behaviours, cognitive patterns and social interaction structure will become more understandable (Reitman, Anderson Coto, Wu, Lee \& Steinkuehler, 2020). Since e-sports, digital games and sports activities became increasingly popular and influence 
young people, it is necessary to investigate this topic with a large scope and multidirectional approach in sociology and psychology fields. At this same time, this subject should be investigated by various scientific fields in terms of positive or negative effects on various aspects such as sports, education, language, culture, media, communication, business, health and law (Özkurt, 2019).

When the content of the studies is investigated, it can be seen that the majority of the e-sports-related sociologic work focus on live e-sports events and social interaction. Sociology-based certain studies focused on gender and identity. Although some of these studies found that inequality is an aspect of sports, it can be said that e-sports offers an opportunity to support diverse culture (Reitman, Anderson Coto, Wu, Lee \& Steinkuehler, 2020). Some qualitative studies focused on the relationship between culture and technology in online games. The cultural and social relationships that emerged in these games were considered from a sociological perspective and how the game type that is a playing culture with its tournaments, gamers, audience and professional computer games turned into a sport (Taylor, 2012). The psychological studies considered the properties such as individuals' process to become an e-sports gamer, mental skills of e-sports gamers, motivations as well as the motivations of esports audience (Bányai, Griffiths, Király, \& Demetrovics, 2019). The researchers in business and computer technologies fields focused on discovering the internal functions and marketing potential of the organisations related to the sector. The communication researchers investigated the game society and virtual communication techniques (DeviaAllen, 2017).

E-sports that has gained a growth acceleration, large budget and a large number of followers around the world influenced a large audience including the young people in Turkey. Despite this observed demand for e-sports at professional, amateur or recreational demand in our country, it can be seen that the number and scope of the related studies are limited (Mustafaoğlu, 2018). To understand, define, identify the development opportunities and holistically investigate the e-sports industry and e-sports, it is necessary to conduct studies related to interdisciplinary theoretical approaches and applications (Cranmer, Han, van Gisbergen \& Jung, 2021). This study aims to investigate e-sports being a new game experience field and socialising tool from a multidimensional perspective.

\section{A. E-Sports}

E-sports is known for different names including electronic sports, electronic game, online game, cybergame, virtual game, professional game, competitive video game, video game and computer game (Hamari \& Sjöblom, 2017; Mustafaoğlu, 2019). E-sports is a sport branch with unique rules, competition, played at the professional or amateur level as individuals or as a team with various stakeholders like game developers, sponsors, teams and audience that includes computer games that use technological infrastructure (Yükçü \& Kaplanoğlu, 2018). Wagner (2006) defined e-sports as a sports branch where cognitive and physical skills are developed by using information technologies (Phalen, 2019). E-sports can be defined as the consumption of video games 
played in a professional and competitive setting broadcasted by individuals' streamers or tournament organisers (Kørschen, 2020). Players form the basis of all sports. Games as sports represent certain types of activities. In this sense, e-sports can be regarded as a game-based activity. E-sports has various game types including competition games, chance games, imitation or simulation games. The most striking game type in the correlation studies between games and sports is defined as competition games (Baltezarević \& Baltezarević, 2018).

E-sports concept is represented with video games played under competitive and professional settings created with digitalisation. Today, technology created a significant impact in the sports field. By using technology, new programs are developed in sports fields and sports is introduced to a wider audience. Fundamentally, e-sports are a concept that existed since the first introduction of computer games but gained popularity in the last decade (Mustafaoğlu, 2019). The period between the 1980s and the 21st century proved that there is an opportunity for e-sports to grow and create competition. Over time, a legitimate event organisation was necessary that ensures mass contribution and sustainable competition in the sports sector. E-sports started at the beginning of the 1990s and the opportunity to benefit from technology emerged with digitalisation. In the last few years, the popularity of e-sports experienced surprising bounces. At the beginning of the 2000s, network innovation facilitated remote video game competition and businesses started to invest in tournament sponsorships and video game contents to form professional teams with gamer sponsorships. The number of gamers in e-sports that gained further popularity in recent years significantly increased. E-sports that has 474 million viewers as of 2021 is estimated to have 577 million global viewers until 2024(Akgöl, 2019; ; Gough, 2021; Kocadağ, 2017; Snavely, 2014; Steinkuehler, 2020).

E-sports became a new media form with the increasing content of online game technologies. Today, hundreds of millions of individuals are following e-sports. E-sports is a type of competition that facilitates video games via electronic systems. Electronic systems facilitate primary aspects of e-sports as a sport branch and create gamer inputs and e-sports system outputs via e-sports interfaces. E-sports include professional and competitive video games on various tournaments and leagues where sports organisations supported by various institutions are a member (Hamari \& Sjöblom, 2017). The emergence of e-sports creates a completely new potential market. These sports with new and different content brought together a unique consumer audience. As the internet gained popularity over the TV in the 21 st century, this played an important role for esports to access its target audience (Marelić \& Vukušić, 2019).

E-sports has certain similarities and differences with traditional sports. E-sports like traditional sports is based on coherent and coordination-based teamwork. Similarly, properties such as team process, member properties and motivation are considered to form high-performance e-sports teams. Additionally, traditional sports and e-sports are similar in terms of their competitive nature and meticulous training process for the players to improve their skills. with that, lack of standardised management structure and work rules in e-sports, self-organisation, business-focused structure, having young 
people as the majority of the audience and a global approach makes it different from the traditional sports. Additionally, since gamers compete in the virtual environment with virtual characters, e-sports are different from traditional sports in terms of competition. Therefore, the motivations of the e-sports audience can be different from the traditional sports audience (Scholz, 2019; Tang, 2018; Xiao, 2020).

While whether e-sports are considered as a sport is discussed, it is important to consider the nature of sports and definitions regarding sports. E-sports has similar properties to traditional sports as it is organised by rules, has competition, requires skill and has a wide audience. However, it is known that it has various shortcomings in terms of institutionalisation and physicality (Mustafaoğlu, 2018). Jenny et al. (2017) suggested that an event must have six properties which are physicality, institutionalisation, rules, the existence of game and competition, skill requirement and large followers to be referred to as sports. Accordingly, it is stated that e-sports have each one of these properties excluding the extend of physicality and institutionalisation (Cranmer, Han, van Gisbergen \& Jung, 2021). When e-sports are considered within the sports concept, certain similarities and differences can be seen. Having individuals' games or team games, skill development being a precondition for success, high harmony expectations in team settings, the importance of mental effort and timing support the sports qualities of e-sports (Şahin, 2018). E-sports offers valuable and unique opportunities to discover team building and team coordination social processes more (Freeman \& Wohn, 2019). E-sports highlighted with the development of internet infrastructure and video games have the quality to be a new study field for researchers with its rich content. E-sports with the discussions of whether e-sports are a sport attracts increasingly more attention with its teams, tournaments and federations (Büyükbaykal \& İli, 2020). E-sports is growing around the world with more participation from gamers or audience. Some studies argue that e-sports are not entirely sports due to its properties but it has the potential to become sports (Hallmann \& Giel, 2018).

\section{B. E-Sports and Socialising}

Sports offer various opportunities for individuals to comply with social life, develop interpersonal interaction and collaboration and develop self-development. Sports not only has a meaning of physical activity field but also supports individuals to gain a social identity and socialise (Küçük \& Koç, 2004). Sport is a phenomenon that gives individuals a chance to improve their social surrounding. With sports, individuals have the opportunity to observe how to act in a social setting and develop their social skills (Yıldız \& Çetin, 2018).

Playing computer games is accepted as a social experience. Millions of gamers are socially interacting with online games which are a new type of game. These games are designed to support the interaction between gamers. It is important to question the nature and structure of these interactions in which the scopes are not entirely discovered (Ducheneaut \& Moore, 2004). Recent studies found that individuals that play computer games experience positive impacts of the games in creating a social network, obeying parents, family relationships, school performance, spatial skills, reaction time and 
avoiding alcohol and drugs (Jonasson \& Thiborg, 2010). Baltezarević and Baltezarević (2019) emphasised that e-sports developed problem-solving skills, cognitive skills, socialisation and emotional health in adults (26-45) participating in amateur e-sports competitions. Studies showed that video games have positive effects on skills such as strategy development, decision-making, harmony, collaboration and motivation (Mustafaoğlu, 2019). Studies revealed that video games allow young adults and young people to develop their social skills with interactions in the games. Although there are numerous benefits for students participating in e-sports, academic institutions need to consider the holistic effects of e-sports participation (Ferguson \& Olson, 2013). Additionally, studies showed that e-sports has a positive effect on creating a social network between team members. These findings provide insight that academic institutions might follow sustainable e-sports program development (West, 2020).

E-sports matches happen when at least two competitors face each other individually or as a team (Kilci \& Yalçıner, 2020). E-sports that has various types such as multiplayer online role-playing, shooting, war and fighting games, as well as real-time sports games and strategy games, are often organised around a certain game type such as multiplayer online games (Pişkin, Devecioğlu \& Halisdemir, 2019). Social relationships in multi-player online games can be explicit or implicit. Explicit relationships are formed when gamers become friends with other people individually with their own initiative. Implicit relationships are passively created by gamers via interactions (Jia, Shen, Bovenkamp, Iosup, Kuipers \& Epema, 2015). In e-sports that rapidly completed the organisation process, certain games and matches were highlighted according to participant and viewer tendency and demand. There are different games and matches that address the different audience on e-sports platforms. Therefore, it is possible to state that certain games are demanded in e-sports just like traditional sports (football, basketball etc.) (Atalay \& Boztepe, 2020).

In modern societies, e-sports are not considered as a sports or especially traditional sports. Instead, e-sports are accepted as a counterculture or an alternative to modern sports (Hallmann \& Giel, 2018). Individuals that comply with modernism got the chance to benefit from technologies that facilitate life. With the technology industry, individuals gained the opportunity to play games via electronic devices they use in everyday life. These developments caused the e-sports concept referred to as professional video gaming that serves the purpose to communicate, spend time, develop skills and entertainment to emerging (Evren, Kargün, Pala \&Yazarer, 2019).

E-sports is similar to the functions of a traditional sports team in terms of forming teams with gamers and communicating with individuals all around the world. While various cultural effects can sometimes damage the group dynamics, it is argued that cultural diversity helps the cognitive development of individuals in a group environment (Gauvain, Beebe \& Zhao, 2011). The interviews with e-sports gamers revealed that having different cultural perspective among few team members helped them to mature and became better person in cognitive, intellectual and emotional terms (Tang, 2018). 
In the 21 st century, all individuals from every age group spend an important part of their lives playing games on their smartphones and computers. It is known that a new game is launched for consumption every day (Bayram, 2018). It is necessary to support e-sports players to be guided to use time effectively and participate in recommended activities in line with functional planning (Mustafaoğlu, 2018). It is possible to assert that the most widespread service among the services that technology offers to humanity is mobile devices. Among the mobile devices, almost every individual has at least one smartphone that the individual uses efficiently. Smartphones are among the devices that create the communication network of all individuals around the world. However, smartphones are not the only tools for communication. In addition to being an important communication need, it has turned into a dynamic device that helps individuals to play games, listen to music and offer navigation apps. Since smartphones and the applications in these phones became usable at any moment with the technological developments in recent years, the applications in the market in smartphones became extremely important (Atalay \& Topuz, 2018).

In the period from the introduction of the internet until now, it has taken an effective role in social change. It is a necessity to investigate how much individuals participate in this ongoing change process and the effects of technological developments on life experiences (Civan Kemiksiz, 2019). In e-sports, teams and individual gamers play games on virtual networks via computer systems and the internet. Electronic sports are known as a more expanded global phenomenon with the development of games. Since digital games enable communication and interaction as they can be played around the world via the internet, socialising opportunities increased (Kartal, 2020).

It is seen that there is a technology revolution with an expanded digital exchange and intense use of internet technologies and computers with artificial intelligence which is also referred to as "Industry 4.0" in society (Kartal, 2020). Technology developing sportive activities in the digital environment was responded positively by the individuals and creators who started to search for creating a social and economic field (Öz \& Üstün, 2019). In this development period, the e-sports industry found itself at a critical stage looking for continuous growth and sustainable development that both offers tremendous opportunities and experiences challenges. Accepting e-sports which is highlighted as a socialising tool to generate income and gain the consumer as an opportunity is highly important for the developing sector (Qian \& Zhang, 2019). Games that are played widespread among young people entered a high-level structuring search. The global high-level structuring created for these games enables young people to participate in tournaments and championships and support their success with titles and rewards (Özsoy \& Kalafat Çat, 2018).

E-sports that has a huge accelerated growth rate around the world and reached millions of followers especially influenced the young people in our society (Mustafaoğlu, 2019). The majority of the e-sports audience consists of a male, students and 20-24 years old individuals living in big cities and studying at undergraduate level (Ecevit, Tunçe, Karaoğlu, Şahin \& Özer, 2018). Similar studies identified that majority of the individuals 
who involve in recreative, professional or amateur e-sports are male, single, student individuals in the 19-25 age group (Akın, 2008).

In the last decade, the concerns related to the effects of playing computer games on the development of young people are increasing. With the rise of e-sports, the teamoriented and competitive structure of the games based on collaboration brought the idea that this style might cause positive behavioural change among young people. Competitive esports teams are a relatively new phenomenon compared to traditional sports such as football, baseball and basketball that are played in an academic setting. In the last decade, both middle school (9-12th grade) and post-high school (college and universities) academic institutions accepted the potential of e-sports and started to apply various programs to benefit from positive aspects of e-sports. The studies show that esports participation develops students' communication skills and leadership talents. The studies obtained findings that competing in an e-sports school tournament caused positive behavioural change for friendship and personal development dimensions of 1219 years old young people (Fletcher, Gowers \& Saeed, 2020; Tang, 2018).

It is possible to mention the multidirectional benefits of spots and games on individuals in social life. Games have an effect to develop the mind, imagination, creative thinking skills, multidimensional and alternative thinking potential of the individuals. Additionally, games help to decrease stress, develop patience, honesty and respect, support teamwork, develop self-control and responsibility, follow the rules and be participative among individuals. Sports help to keep individuals away from stress, help individuals to be healthy and happy, develop talents, socialise, develop collaboration and competition-based communication, self-realised and achieve gains (Özkurt, 2019).

The aim of this study is to provide a multidimensional perspective by examining the views of teacher candidates' on e-sports. In this context, answers to the following questions were sought in the study:

1. What are the opinions of primary school teacher candidates regarding what e-sports is?

2. What are the opinions of primary school teacher candidates about the effects of esports?

3. What are the opinions of classroom teacher candidates about the effect of E-sports on individuals' socialization?

4. What are the opinions of the classroom teacher candidates regarding the career process regarding E-sports?

\section{Method}

This study uses a case study pattern among qualitative research methods. The main purpose of a case study is an in-depth investigation of a situation. In case of studies, the subject could be an individual, group, institution or environment (Yıldırım \& Şimşek, 2016). A case study investigates why and how questions in detail. In the case of studies, 
there are theoretical explanations that might help to understand similar situations and events without the purpose of finding a general conclusion (Seggie \& Bayyurt, 2015).

\section{A. Study Group}

The study group of this research consisted of 22 teacher candidates' studying in the Primary School Teaching Program in the Primary Education Department of Education Faculty of İnönü University in the 2020-2021 academic year. A total of 23 students of which 10 were male and 12 were female participated in this study. The students are determined with criterion sampling among purposeful sampling methods. The criterion was selected as to be has e-sports experience. To comply with ethical rules, the participation teacher candidates' are coded as K1....K23.

Table 1 Demographic Features

\begin{tabular}{ll}
\hline Independent Variables & $\mathrm{f}$ \\
\hline Gender & 10 \\
\hline Female & 13 \\
Male & 9 \\
\hline Gaming Preferance & 7 \\
\hline PC & \\
Notebook & 5 \\
Mobile Phone & 1 \\
Tablet & \\
Gaming Console & 1 \\
\hline
\end{tabular}

\section{B. Data Collection}

The data were collected with a semi-structured interview form developed by researchers. Support from 3 field experts was received when the form was created. The interview is one of the qualitative research methods commonly used for systematic data collection in social sciences. It is expressed as the shortest way to understand various knowledge, thought, attitudes and behaviours of individuals and their possible reasons (Creswell, 2016; Merriam, 2013; Patton, 2014). According to Merriam (2013), interviews can be conducted to reveal the reason for unobserved behaviours, learn the 
emotions, views and believes of individuals about events/phenomenon and according to Patton (2014), interviews can be conducted to reveal the experiences of the individuals, learn how the events affect individuals and learn about the changes in emotions and views. An interview form prepared by the researcher with 4 open-ended questions was used for data collection in this study. This form was shared with teacher candidates' in an online environment and the teacher candidates' were asked to complete and send the form in 3 days via an online environment. Before the application, online interviews were conducted with the teacher candidates' via Zoom, the purpose of the study was explained and the importance of correctly answering the question was explained. The researchers collected the received e-mails and created a data file.

\section{Data Analysis}

The data collected for this study were analysed with content analysis. Content analysis that gathers similar data and interprets this data for the reader to understand represents the results descriptively after in-depth analysis. In content analysis, the data are processed according to four stages which are coding, creating themes, organising data for codes-themes and defining-interpreting findings to conclude (Yıldırım \& Şimşek, 2016). In content analysis, the researcher is directed to explain the collected data. After the data is filtered in detail, the data is interpreted around a certain subject and transferred to the reader (Gürbüz \& Şahin, 2018).

\section{D.Ethical Committee Decision}

Ethical permission was obtained from the 22.04 2021/8-43 Inonu University Social and Humanities Scientific Research Ethical Committee for this research.

\section{III.Findings}

The findings obtained from this study, which was carried out to reveal the opinions of teacher candidates' on E-sports, were grouped into four categories, and the tables belonging to each category are given below.

\section{A. Findings regarding the opinions of the teacher candidates' about E- sports}

Table 2. The opinions of the teacher candidates' about E-sports

\begin{tabular}{lll}
\hline Themes & Codes & F \\
\hline Digital Environment Sport & Internet use & 20 \\
& Digital Game & 20 \\
& Online participation & 17 \\
& Digital characters & 8 \\
\hline Internationality & Simultaneous tournament & 3 \\
\hline Electronic Sports & Professional players & 16 \\
Organizations & Team play & 4 \\
& Individual play & 4
\end{tabular}




\begin{tabular}{llc} 
& Online audience & 3 \\
& Different branches & 2 \\
& Reward system & 1 \\
\hline Effects & Physical relaxation & 4 \\
& Spiritual relaxation & 3 \\
& Control skill development & 2 \\
\hline $\begin{array}{l}\text { Not falling into the sports } \\
\text { category }\end{array}$ & Physical activity deprivation & 2 \\
\hline
\end{tabular}

The teacher candidates' shared their opinions on E-sports under 15 different codes in 5 themes. Accordingly, it can be said that teacher candidates see E-sports as online participation-based digital games that require more internet use. Some examples from the opinions of teacher candidates' on e-sports are presented below.

K2: "It is a sports branch based on online games. Electronic sports can be defined as a sport where people from all over the world can meet and play games via the internet, or people from different parts of the world can meet and play games through large international electronic sports organizations organized at certain times. Games get this name when they are organized with professional organizations, usually among professional players."

K4: "Contrary to mainstream sports, it does not involve a physical activity, it is a type of activity that involves controlling any game."

K16: "Ability to perform sports in different branches over the Internet."

\section{B. Findings on the opinions of teacher candidates' on the effects of e- sports}

Table 3 The opinions of teacher candidates' on the effects of e-sports

\begin{tabular}{lll}
\hline Themes & Codes & f \\
\hline Positive Effects & Motor skill development & 8 \\
& Socialization & 8 \\
Foreign language acquisition & 6 \\
Supporting teamwork & 3 \\
Supporting leadership development & 2 \\
Technological knowledge development & 2 \\
Positive motivation to sport & 2 \\
Avoidance of stress & 1 \\
Increasing attention span & 1 \\
& Providing personal development & 1 \\
& opportunities & \\
Barrier-free environment & 1 \\
& Being free from discrimination & 1
\end{tabular}




\begin{tabular}{|c|c|c|}
\hline & Getting to know different cultures & 1 \\
\hline & Developing creative thinking & 1 \\
\hline & Developing strategic thinking & 1 \\
\hline & Developing analytical thinking & 1 \\
\hline & Developing problem solving skills & 1 \\
\hline & Developing responsibility & 1 \\
\hline & Material return & \\
\hline \multirow[t]{11}{*}{ Negative Effects } & Physical activity deprivation & 7 \\
\hline & Addiction & 7 \\
\hline & Asocialization & 6 \\
\hline & Health problems & 4 \\
\hline & Falsity & 3 \\
\hline & Loss of communication & 2 \\
\hline & Academic failure & 2 \\
\hline & Obesity & 1 \\
\hline & Distractibility & 1 \\
\hline & Incitement to violence & 1 \\
\hline & Production based on commercial concern & 1 \\
\hline
\end{tabular}

The teacher candidates' shared their opinions on the effects of E-sports under 30 different codes in two themes. Accordingly, it can be said that while teacher candidates' emphasized the positive effects of e-sports as motor skill development, they saw physical activity deprivation and addiction as negative effects. While some teacher candidates' saw e-sports as a means of socialization, some reported that it would cause asocialization as a result of digital addiction. Some examples from the opinions of teacher candidates' on the effects of e-sports are given below.

Positive effects theme

K1: "Learning teamwork, 2- Many players communicate in different languages with players from different cultures and learn languages on the computer. 3- Stratejik, analitik düşünme ve hıll karar verebilme yeteneği sağlaması Providing the ability to think strategically, analytically and deciding quickly, 4- Providing hand, eye and mind coordination, 5-Increasing technological knowledge and skills, 6- Recognizing different cultures and making friends with people from different cultures, 7- The basis of games is mathematics and accordingly, many lessons around the world are taught to children through games, 8-Increasing task management in children who play strategy games, 9Developing leadership qualities"

K.9. "In the time when everything has started to go digital, it is possible to both play games and earn money with e-sports via tournaments etc.." 


\section{Negative effects theme}

K.17. "Inactivity can lead to laziness. It may cause pain and degree progression over the eyes."

K.9. "There may be problems with asociality and human relations, although I have not experienced this as someone who plays a lot, there are examples of people experiencing. It varies from person to person."

\section{Findings of the opinions of teacher candidates' on the effect of e- sports on the socialization of individuals}

Table 4 Opinions of teacher candidates' about the effect of e-sports on the socialization of individuals

\begin{tabular}{llr}
\hline Themes & Codes & \\
\hline Contributing to socialization & Being competitive & 1 \\
& In-game solidarity & 1 \\
& In-game solidarity & 3 \\
& Internationality & 1 \\
& Covid-19 Pandemic time socialization & 1 \\
& Virtual friendships & 2 \\
\hline Causing asociality & Digital screen addiction & 1 \\
& Incitement to aggression & 1 \\
& Lack of physical interaction & 3 \\
\hline
\end{tabular}

Teacher candidates' expressed their opinions on the effect of e-sports on the socialization of individuals under nine different codes in two themes. While some teacher candidates' explained the contribution of e-sports to socialization with the codes of being competitive, in-game solidarity, mutual interest meeting, internationality, Covid-19 Pandemic time socialization and virtual friendships, some teacher candidates' stated digital screen addiction, incitement to aggression and lack of physical interaction caused asociality. Some examples from the opinions of teacher candidates' on e-sports are presented below.

The theme of contributing to socialization

K.7. "It is a good activity for socializing, because people who have difficulty in expressing themselves and who do not have good social relations can socialize more easily in digital environments for the purpose of in-game solidarity. If you are an introverted, secretive person, you can take the first step to socialization with e-sports." 
K.13. "E-Sports tournaments are now held with spectators. E-sports tournaments contribute as much as a basketball tournament contributes to socialization."

The theme of causing asociality

K.17. "I think it restricts socialization because no matter it is called a group sport, training processes will be far from sociality, in general."

\section{Findings of the opinions of teacher candidates' on the career process of e-sports}

Table 5 The opinions of teacher candidates' on the career process of e-sports

\begin{tabular}{llc}
\hline Themes & Codes & f \\
\hline Positive Perspective Toward & Student interest & 4 \\
Directing to E-Sports & Student success & 2 \\
& Informinge & 2 \\
& Appropriate infrastructure & 1 \\
& Being usseful & 1 \\
& Being safe & 1 \\
\hline Negative Perspective Toward & Having a career without socializing & 2 \\
Directing to E-Sports & Leisure activity & 1 \\
& Inability to use excess energy & 1 \\
& Hindering development & 1 \\
\hline
\end{tabular}

Teacher candidates' expressed their opinions on the effects of e-sports on the career process under ten different codes in two themes. According to this situation teacher candidates' have a positive perspective toward career development in e-sports if their students have interest and ability in this field, and if there is appropriate infrastructure. It can be said that the teacher candidates' have a negative perspective toward career development in e-sports for some reasons, such as lack of socialization, lack of physical activity to use their excess energy and hindering development. Some examples from the opinions of teacher candidates' on the effects of e-sports on career process are given below.

The Theme of Positive Perspective Toward Directing to E-Sports

K.6. "If I realize that my students have an interest in this direction, I will do the necessary research and direct my students to this field in the most productive way."

The Theme of Negative Perspective Toward Directing to E-Sports

K2: "What you call e-sports, after all, is another bubble economy, one of the new methods of selling something that has not materialized in the physical environment, so 
this bubble will burst one day when the supply and demand side is satisfied. That's why, it can be a waste of time."

\section{Results, Discussion and Recommendations}

Technological developments affect sports directly or indirectly, as in all other social areas. These developments have led to the emergence of electronic sports. E-sports represents competitive video games that make traditional sports a part of the virtual world. E-sports has become a new media form with the increasing content of online gaming technologies. Today, hundreds of millions of people follow e-sports. Researching the role of e-sports in the socialization process of individuals plays an important role. In this study, it is aimed to provide a multidimensional perspective by examining primary school teacher candidates' views on e-sports. In this context, the views of primary school teacher candidates on what e-sports is, its effects, its effects on the socialization of individuals and the career process in e-sports were examined.

When the opinions of the primary school teacher candidates on the meaning of esports were examined, it was determined that the teacher candidates defined e-sports as digital games based on online participation that require more internet use. Çolak et al. (2018) determined in their research that $63.5 \%$ (181) of the participants did not know the meaning of the word e-sports. $11.9 \%$ of the participants stated that they learned the meaning of e-sports from the internet, and $10.8 \%$ said they learned it from their friend. When the opinions on what e-sports are, $17.8 \%$ of the participants prefer e-sports to online games, $12.9 \%$ to electronic sports competitions, $6.3 \%$ to waste of time, unnecessary and harmful things. It was determined that $5.6 \%$ of them described it as the future of sports, $2.8 \%$ as a way to earn money by playing games, $2.8 \%$ as a sports and news site, and $1.7 \%$ as inactive sports.

When the opinions of the teacher candidates on the effects of e-sports are examined, it is seen that the teacher candidates express the development of motor skills as a positive effect of e-sports, and the lack of physical activity and addiction as a negative effect of e-sports. While some of the teacher candidates saw e-sports as a socialization tool, some stated that it would cause asocialization as a result of digital addiction. Widely used video games come with some risks, including the risk of addiction and potential health risks. Video game applications may not always present problematic situations for individuals. These practices can also have potential positive effects on individuals. For this reason, it is more functional to evaluate the positive and negative effects of applications together when evaluating video games (Thorens et al., 2016). Theoretically, the views that games are an inefficient activity, violent video games encourage aggressive behaviors, video games cause gaming addiction, and e-sports lead to e-sports related gambling addiction are the main reasons why society has a negative perception about video games (Freitas et al., 2019). Choi et al. (2017) emphasized that success and risk-taking impulses are the strongest predictors of e-sports addiction in their study. In the research, it was determined that e-sports participants value competition equally regardless of their addiction level. In addition, risk taking has been expressed as an important participant motivation that affects e-sports addiction. Whether gaming causes addiction or not continues to be discussed in the scientific literature. The American Psychiatric Association has proposed 
the concept of "internet gaming disorder" in relation to the subject. It is stated that many passionate individuals who are committed to e-sports games often find themselves in this activity to the extent that it can reduce their interest in other activities. This reflects a certain passionate state that is not addictive. As a result, it can be misinterpreted as a devotional addiction. Gamers use the concept of healthy gaming culture to position esports as a viable sport. E-sports is turned into a sport by focusing on sportsmanship, team spirit, healthy nutrition, physical exercise and similar elements (Nielsen \& Hanghøj, 2019). Granic et al. (2014) stated that video games have positive effects on social, emotional, motivational and cognitive well-being.

When the opinions of the teacher candidates on the effects of e-sports on the socialization of individuals were examined, it was determined that some teacher candidates explained the effect of e-sports on socialization with the codes of being competitive, solidarity in the game, meeting of mutual interests, internationality, Covid19 Pandemic time socialization and virtual friendship codes. Some teacher candidates explained the effect of e-sports on socialization with the codes of asociality experienced due to digital screen addiction, incitement to aggression and lack of physical interaction. Seo (2016) stated in his research that e-sports contains various social meanings and values. With these social meanings and values, e-sports is becoming a symbolic expression of personal development, competitiveness, justice and respect for individuals, rather than just a daily leisure activity or a form of work for individuals. In this respect, e-sports consumption encourages a whole new social world. In the research, most of the participants stated that their social interactions with other e-sports players increased and they established personal friendships that improved their social identities. Along with the e-sports events, the participants made friends with whom they communicated outside the virtual world. It has been determined that there are many social reasons why consumers prefer to be professional players and make a career in e-sports. Among these reasons are professional players meeting their socialization needs by developing positive relationships among themselves, achieving positive results in tournaments by advancing in their careers, experiencing a sense of self-realization by receiving positive reinforcement from their peers in their success, and taking an inner pleasure from esports activities (Seo, 2016).

When the opinions of the primary school teacher candidates about the career process in e-sports are examined, it is seen that the teacher candidates have a positive view of the e-sports career development process in terms of benefiting from e-sports, being interested in e-sports, being talented in this regard, and having a suitable infrastructure; On the other hand, it can be said that they view them negatively in terms of lack of socialization, lack of physical activity to use their excess energy and hindering development. There are many reasons that lead individuals to be interested in e-sports. Mustafaoğlu et al. (2018) stated in their research that individuals are most interested in e-sports for reasons that can be expressed as passion for games, then career and leisure time. Career development in e-sports is a complex and dynamic system. Meng-Lewis et al. (2020) stated in their study that traditional career theories may be insufficient to explain the complex and dynamic nature of careers that occur with e-sports. They have 
made an important theoretical contribution by developing an e-sports career theory that is compatible with the contemporary environment and aimed at developing e-sports skills. More and more gamers see esports as a career opportunity rather than a recreational activity. Social motivations based on competition and skill development bring along career planning to become a professional e-sports player. Young players have more opportunities to seek a career as a professional e-sports player than other players with competitive gaming experience (Bányai et al., 2020). There are countless ways to participate in esports: event hosting, web design, audio streaming, game analytics, legal protection, and many other integrated events. These roles are crucial for the growth of the surrounding community and tournaments (Anderson et al., 2018).

In the light of the results obtained, it is thought that various projects and training programs aimed at enabling young people to get to know e-sports may be beneficial. In addition, considering the negative effects of e-sports, it can be suggested that young people be guided correctly through trainings in order to avoid these risks. Considering the positive effects of e-sports events, directing young people to participate in these events as amateur and professional will support their development in a versatile way. With the dimension of e-sports as a new gaming experience area and a new socialization environment, it is important to provide an encouraging environment for young people to create a social identity and realize their social goals. It will be beneficial to act with a scientific perspective in the discovery of the potential of individuals and the development of their skills in e-sports events. In this respect, providing scientific approaches and training programs such as identifying the talents of young people, directing them to activities suitable for their potential, and planning the usage hours are important in terms of functionality. Establishing a healthy gaming culture will also make it easier for individuals to become professional in e-sports and realize their career goals related to esports. Based on the results obtained, it can be suggested to researchers to conduct qualitative research on different study groups to determine the effects of e-sports on individuals. Evaluations regarding e-sports as a gaming experience area and a socialization tool can also be made through quantitative research. Researchers can also conduct experimental studies on the effects of e-sports on social relationship roles.

\section{References}

Akgöl, O. (2019). Spor endüstrisi ve dijitalleşme: Türkiye'deki espor yapılanması üzerine bir inceleme. TRT Akademi, 4(8), 206-224.

Akın, E. (2008). Elektronik spor: Türkiye'deki elektronik sporcular üzerine bir araştırma. (Yayımlanmamış Yüksek Lisans Tezi). Anadolu Üniversitesi Sağlık Bilimleri Enstitüsü, Eskişehir.

Anderson, C. G., Tsaasan, A. M., Reitman, J., Lee, J. S., Wu, M., Steel, H., Turner, T., \& Steinkuehler, C. (2018).Understanding Esports as a STEM Career Ready Curriculum in the Wild,10th International Conference on Virtual Worlds and Games for Serious Applications (VS-Games), pp. 1-6.

Atalay, A. \& Boztepe, E. (2020). E-spor endüstrisi ve ekonomik çıktıları üzerine bir değerlendirme. Journal of Accounting, Finance and Auditing Studies, 6(3), 19-35. 
Atalay, A.,\&Topuz, A. C. (2018). What is being played in the world? Mobile esport applications. Universal Journal of Educational Research 6(6): 1243-1251.

Baltezarević, B. \& Baltezarević, V. (2019). eSports as a new playground. Facta Universitatis, Series: Physical Education and Sport, 023-030.

Baltezarević, R., \& Baltezarević, B. (2018). The impact of video games on the esports formation. Facta Universitatis, Series: Physical Education and Sport, 16(1), 137147.

Bányai, F., Griffiths, M. D., Király, O.ve Demetrovics, Z. (2019). The psychology of esports: A systematic literature review. Journal of gambling studies, 35(2), 351-365.

Bányai, F., Zsila, Á., Griffiths, M. D., Demetrovics, Z., \& Király, O. (2020).Career as a Professional Gamer: Gaming Motives as Predictors of Career Plans to Become a Professional Esport Player. Frontiers in Psychology, 11.

Bayram, A. T. (2018). Planlanmış davranıș teorisi çerçevesinde e-spor turizmine katılma niyeti. Turizm Akademik Dergisi, 5(2), 17-31.

Büyükbaykal, N. G. \& İli, B. (2020). E-spor kavramına yönelik araştırmaların bibliyometrik analizi. Uluslararası Kültürel Ve Sosyal Araştırmalar Dergisi (Uksad), 6(2), 572-583.

Choi, C., Yoo, S.-W., \& Greenwell, T. C. (2017). A new approach via level of addiction in eSports: Investigating participation motives from a marketing perspective. In Sport Marketing Association Conference (SMA XV) (pp. 1-3).

Civan Kemiksiz, R. (2019). Çevrimiçi bağımlılığın habitatı: çevrimiçi oyuncuların espor faaliyetleri ve oyun bağımlılı̆̆ ilişskisi. (Yayımlanmamış Yüksek Lisans Tezi). İstanbul Üniversitesi Sosyal Bilimler Enstitüsü, İstanbul.

Cranmer, E. E., Han, D. I. D., van Gisbergen, M.ve Jung, T. (2021). Esports matrix: Structuring the esports research agenda. Computers in Human Behavior, 117, 106671.

Creswell, J. W. (2016). Nitel araştırma yöntemleri, beş yaklaşıma göre nitel araştırma ve araştırma deseni [Qualitative research methods, qualitative research and research design according to five approaches]. (M. Bütün \& S. B. Demir, Çev. ed./Trans. ed.) Ankara: Siyasal Kitabevi.

Çolak, S., Örs, A., Çolak, E., Son, M., Güzelordu, D., Çolak, T., \& Yargıcı, M. (2018).Spor Bilimleri Fakültesi öğrencilerinin e-spor bilgi düzeylerinin araştııılması. Kocaeli Üniversitesi Sosyal Bilimler Dergisi, (35), 121-127.

Devia-Allen, G. C. (2017). Good game well played: An esports documentary. Illinois State University.

Ducheneaut, N., \& Moore, R. J. (2004). The social side of gaming: a study of interaction patterns in a massively multiplayer online game. In Proceedings of the 2004 ACM conference on Computer supported cooperative work (360-369).

Ecevit, R. G., Tunçe, F., Karaoğlu, O., Şahin, E. \& Özer, M. K. (2018). Elektronik spor ve elektronik sporcular üzerine betimsel bir inceleme. Journal Of Health And Sport Sciences, 1(1), 23-28.

Evren, T., Kargün, M., Pala, A. \& Yazarer, İ. (2019). Spora yenilikçi yaklaşım: espor. Journal Of International Social Research, 12(66). 
Ferguson, C. J., \& Olson, C. K. (2013). Friends, fun, frustration and fantasy: Child motivations for video game play. Motivation and Emotion, 37(1), 154-164.

Fletcher, B., Gowers, R., \& Saeed, S. (2020, November). The Effects of Esports School Tournaments on Positive Behavioural Change. In Joint International Conference on Serious Games (pp. 219-229). Springer, Cham.

Freeman, G. \& Wohn, D. Y. (2019). Understanding eSports team formation and coordination. Computer supported cooperative work (CSCW), 28(1), 95-126.

Freitas, B. D. A., Contreras-Espinosa, R. S., \& Correia, P. Á. P. (2019). How Society's Negative View of Videogames Can Discourage Brands from Sponsoring eSports. In International Conference on Videogame Sciences and Arts (pp. 136-149). Springer, Cham.

Gauvain, M., Beebe, H., \& Zhao, S. (2011). Applying the cultural approach to cognitive development. Journal of Cognition and Development, 12(2), 121-133.

Gough, C. (2021). Worldwide eSports audience size 2021 (eSports audience size worldwide from 2019 to 2024). https://www.statista.com/statistics/1109956/globalesports-audience/

Granic, I., Lobel, A., \& Engels, R. C. M. E. (2014).The benefits of playing video games. American psychologist, 69(1), 66.

Gürbüz, S. \& Şahin, F. (2018). Sosyal Bilimlerde Araştırma Yöntemleri. Ankara: Seçkin Yayıncilık.

Hallmann, K. \& Giel, T. (2018). eSports-Competitive sports or recreational activity?. Sport management review, 21(1), 14-20.

Hamari, J., \& Sjöblom, M. (2017). What is eSports and why do people watch it?.Internet research, 27 (2) (2017)

Jenny, S. E., Manning, R. D., Keiper, M. C., \& Olrich, T. W. (2017).Virtual (ly) athletes: where eSports fit within the definition of "Sport". Quest, 69(1), 1-18.

Jia, A. L., Shen, S., Bovenkamp, R. V. D., Iosup, A., Kuipers, F., \& Epema, D. H. (2015). Socializing by gaming: Revealing social relationships in multiplayer online games. ACM Transactions on Knowledge Discovery from Data (TKDD), 10(2), 129.

Jonasson, K., \& Thiborg, J. (2010). Electronic sport and its impact on future sport. Sport in society, 13(2), 287-299.

Kartal, M. (2020). Küreselleşme bağlamında Türkiye'de e-spor. (Yayımlanmamış Yüksek Lisans Tezi). İnönü Üniversitesi Sağlık Bilimleri Enstitüsü, Malatya.

Kilci, A. K., \& Yalçıner, S. (2020). Dijital spor oyunları oynama motivasyonunun ahlâki karar alma tutumlarına etkisi: espor oyuncuları üzerine bir araştırma. Social Sciences Studies Journal, 6(68), 3641-3649.

Kocadağ, M. (2017). Elektronik spor kariyeri ve eğitim. Doğu Anadolu Sosyal Bilimlerde Eğilimler Dergisi, 1(2), 49-63.

Kørschen, T. H. (2020). eSports Behind the Screen. How consumers co-create meaning in practice (Master's Thesis).

Küçük, V.,\& Koç, H. (2004). Psiko-sosyal gelişim süreci içersinde insan ve spor ilişkisi. Dumlupınar Üniversitesi Sosyal Bilimler Dergisi, 9(1), 211-223. 
Marelić, M.\& Vukušić, D. (2019). E-sports: Definition and social implications. Exercise and Quality of Life, 11(2), 47-54.

Meng-Lewis, Y., Wong, D., Zhao, Y., \& Lewis, G. (2020). Understanding complexity and dynamics in the career development of eSports athletes. Sport Management Review.

Merriam, S. B. (2013). Nitel araştırma desen ve uygulama için bir rehber [Qualitative research A guide to design and implementation]. (S. Turan, Çev. ed./Trans. ed.). Ankara: Nobel Akademik Yayıncllı.

Mustafaoğlu, R. (2018). E-spor, spor ve fiziksel aktivite. Ulusal Spor Bilimleri Dergisi, 2(2), 84-96.

Mustafaoğlu, R., Zirek, E., \& Yasacı, Z. (2018). E-Spor oyuncularının demografik özellikleri, oyun oynama süreleri ve başarılarını etkileyen faktörler. Bă̆ımlıllk Dergisi, 19(4), 115-122.

Mustafaoğlu, R. (2019). E-spor ve sağlık. Current Addiction Research, 3(1), 5-10.

Nielsen, R. K. L., \& Hanghøj, T. (2019, October). Esports skills are people skills. In Proceedings of the 13th European Conference on Game-Based Learning (pp. 535542).

Öz, N. D.,\&Üstün, F. (2019). E-spor katılım motivasyonu ölçeği'nin (ekmö) geçerlik ve güvenirlik çalışması. Türk Spor Bilimleri Dergisi, 2(2), 115-125.

Özkurt, A. (2019). E-sporun türkiye'de spor yönetimi ve kulüpleşme yönünden gelişiminin incelenmesi. (Yayımlanmamış Yüksek Lisans Tezi). Ondokuz Mayıs Üniversitesi Sosyal Bilimler Enstitüsü, Samsun.

Özsoy, S.,\& Kalafat Çat, A. (2018). Sanal ortamda sporun yeni formu: e-spor. Journal Of Social And Humanities Sciences Research, 5(31), 4776-4784.

Patton, M. Q. (2014). Nitel araştırma yöntemleri, beş yaklaşıma göre nitel araştırma ve araştırma deseni. [Qualitative research methods, qualitative research and research design according to five approaches]. (M. Bütün \& S. B. Demir, Çev. ed./Trans. Ed) Ankara: Siyasal Kitabevi.

Phalen, Q. P. (2019). Are Esports a Sport?. The University of Edinburgh.

Pişkin, E., Devecioğlu, S.\&Halisdemir, T. A. (2019). Spor endüstrisinin yükselen alanı e-sporun dünya ekonomisindeki yeri. Uluslararası Ekonomi Araştırmaları ve Finansal Piyasalar Kongresi, Gaziantep, 7-9 Kasim 2019, 264-280.

Qian, T. Y.\& Zhang, J. J. (2019). Understanding and Measuring Esports Online Spectator Motivation: Development of a Scale. Association of Marketing Theory and Practice Proceedings 2019. 57.

Reitman, J. G., Anderson Coto, M. J., Wu, M., Lee, J. S.\&Steinkuehler, C. (2020). Esports research: A literature review. Games and Culture, 15(1), 32-50.

Scholz T.M. (2019) Introduction: The Emergence of eSports. In: eSports is Business. Palgrave Pivot, Cham.

Seggie, F. N. \& Bayyur, Y. (Ed.), Nitel araştırma yöntemlerine giriş (3. Baskı, ss. 1274). Anı Yayıncilik. 
Seo, Y. (2016). Professionalized consumption and identity transformations in the field of eSports. Journal of Business Research, 69(1), 264-272.

Snavely, T. L. (2014). History and analysis of eSport systems (Doctoral dissertation).

Steinkuehler, C. (2020). Esports research: Critical, empirical, and historical studies of competitive videogame play. Games and Culture, 15(1), 3-8.

Şahin, M.F. (2018). Elektronik sporcular ile amatör futbol kalecilerinin reaksiyon zamanlarının incelenmesi. (Yayımlanmamış Yüksek Lisans Tezi). Ondokuz Mayıs Üniversitesi Sağlık Bilimleri Enstitüsü, Samsun.

Tang, W. (2018). Understanding esports from the perspective of team dynamics. The Sport Journal, 21, 1-14.

Thorens, G., Achab, S., Rothen, S., Khazaal, Y., \& Zullino, D. (2016). Is video game addiction a reality?. Revue medicale suisse, 12(531), 1554-1556.

Taylor, T. L. (2012). Raising the stakes: E-sports and the professionalization of computer gaming. Mit Press.

Üçüncüoğlu, M.,\& Çakır, V. O. (2017). Modern spor kulüplerinin espor faaliyetlerine ilgi gösterme nedenleri üzerine bir araştırma. İönü Üniversitesi Beden Ĕ̆itimi ve Spor Bilimleri Dergisi, 4(2), 34-47.

Wagner, M. (2006). On the scientific relevance of eSport, in Proceedings of the 2006 International Conference on Internet Computing and Conference on Computer Game Development, CSREA Press, Las Vegas, Nevada, 437-440.

West, C. A. (2020). E-Sports in Academia: A Comparative Analysis of Secondary and Post-Secondary E-Sports Athletes' Experiences (Doctoral dissertation, Lamar University-Beaumont).

Xiao, M. (2020). Factors influencing eSports viewership: An approach based on the theory of reasoned action. Communication \& Sport, 8(1), 92-122.

Yıldırım, A., Şimşek, H., (2016), Sosyal Bilimlerde Nitel Araştırma Yöntemleri, (11. basım), Seçkin Yayıncılık: Ankara.

Yıldız, E., \& Çetin, Z. (2018). Sporun psiko-motor gelişim ve sosyal gelişime etkisi. Hacettepe Üniversitesi Sağllk Bilimleri Fakültesi Dergisi, 5(2), 54-66.

Yükçü, S.\& Kaplanoğlu, E. (2018). E-spor endüstrisi. Uluslararası Íktisadi ve İdari Incelemeler Dergisi, 533-550. 